CATALLAXY

Volume 2 Issue 2 December 2017

e-ISSN 2544-090X

¿ www.catallaxy.pl

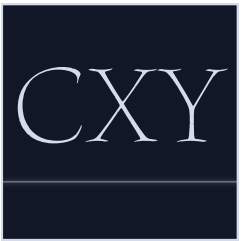

Oryginalny artykut naukowy

otrzymano: 31.10.2017 / zaakceptowano: 01.12.2017 / opublikowano online: 31.12.2017

()(1)

Dudkiewicz, N. (2017). Wskaźniki handlu międzynarodowego a wybrane aspekty dziatalności Indykpol SA w latach 2011-2016. Catallaxy, 2(2): 51-58. doi:10.24136/cxy.2i2.5.

\title{
Wskaźniki handlu międzynarodowego a wybrane aspekty działalności Indykpol SA w latach 2011-2016
}

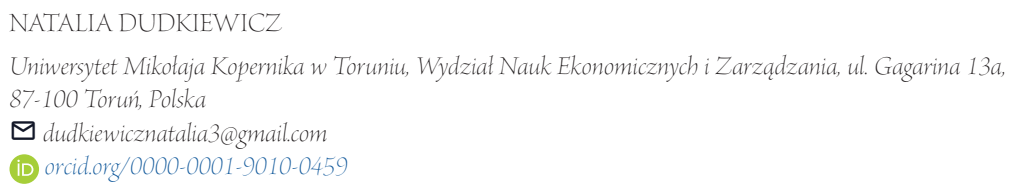

\section{Abstrakt}

Motywacja: Wzrost spożycia mięsa drobiowego oraz większa dbałość konsumentów o zdrowie, wpłynęły pośrednio na rozwój branży drobiarskiej w Polsce. Specyfika tej branży oraz interpretacja postępujących w niej zmian, której brakuje w literaturze przedmiotu, były głównym motywem wyboru tematu niniejszego artykułu.

Cel: Celem artykułu jest wykazanie związku między wskaźnikami handlu międzynarodowego branży drobiarskiej a wybranymi wynikami działalności Indykpol.

Wyniki: Na podstawie przeprowadzonej analizy wykazano, że istotny wplyw na wybrane zmienne dotyczące działalności Indykpol ma współczynnik konkurencyjności. W przypadku współczynnika przewagi komparatywnej nie wykazano zależności między zmiennymi.

Stowa kluczowe: branża drobiarska; wskaźniki handlu międzynarodowego; analiza korelacji liniowej; Indykpol JEL: CO2; F10; 010

\section{Wprowadzenie}

W ostatnich latach można zaobserwować zmiany w sposobie odżywiania. Konsumenci, $\mathrm{w}$ trosce o racjonalne i zdrowe odżywianie, poszukują mięsa o wysokiej wartości odżywczej. Systematyczny wzrost konsumpcji mięsa drobiowego jest także związany $z$ obfitością oferowanego asortymentu i łatwością przygotowania.

Produkcja mięsa drobiowego podlega wahaniom, które zależą m.in. od wielkości i struktury spożycia mięsa oraz od wysokości cen skupu żywca i poziomu cen detalicznych mięsa i jego przetworów. Według danych
Głównego Urzędu Statystycznego (GUS), perspektywy dla branży drobiarskiej są bardzo optymistyczne.

Indykpol SA (dalej Indykpol), jest liderem grupy kapitałowej zajmującej się produkcją mięsa oraz przetworów $z$ drobiu. Indykpol jest największym w Polsce producentem mięsa i przetworów indyczych, w segmencie produktów drobiowych posiada $20 \%$ udział na rynku mięsnym. Spółka stała się ambasadorem polskiego drobiarstwa. Jej produkty, od ponad 20 lat, są dostępne na rynkach zagranicznych. Indykpol szczególną uwagę zwraca na jakość i bezpieczeństwo wytwarzanych produktów. Systemami jakości funkcjonującymi w spółce 
są: HACCP (Hazard Analysis and Critical Control Points), ISO 90001, IFS (International Food Standard), BRC (British Retail Consortium) oraz system QAFP (Quality Assurance For Food Products).

Celem niniejszego artykułu jest wykazanie związku między wskaźnikami handlu międzynarodowego branży drobiarskiej a wybranymi wynikami działalności Indykpol w latach 2011-2016.

W Sekcji 2. artykułu dokonano przeglądu literatury dotyczącej pojęć związanych $z$ handlem międzynarodowym oraz analizą korelacji. W Sekcji 3. zawarto opis wykorzystywanych metod. W Sekcji 4. przedstawiono wyniki badania, które podsumowano w Sekcji 5.

\section{Przegląd literatury}

Kwestia rozwoju branży drobiarskiej jest stosunkowo nowym zagadnieniem, $z$ tego względu, w literaturze podmiotu występuje relatywnie mało publikacji dotyczących tego aspektu. Również niewiele wskaźników handlu międzynarodowego odnoszących się do branży drobiarskiej, zostało obliczonych i zinterpretowanych.

Za twórcę wskaźnika przewagi komparatywnej uznaje się B. Balassa (wskaźnik Balassy). Kwestie dotyczące istoty wskaźnika oraz wzoru zaprezentował M. Olczyk (2008). Wskazuje on, kiedy zachodzi poprawa pozycji konkurencyjnej danego państwa lub produktu. Odnosząc się do definicji przewagi komparatywnej $w$ danym państwie, P. Krugman i M. Obstfeld (2007), określają, kiedy można mówić o takim zjawisku. M. Lubiński i in. (1995), prezentują wskaźnik hipotetycznego eksportu, jego założenia, wzór i interpretację otrzymanych wyników. Podkreślają, czym jest konkurencyjność i do jakich okresów ona się odnosi. Ostatnia część niniejszego artykułu odnosi się do analizy korelacji liniowej. S. Kuroś (2005), opisuje analizę oraz przedstawia podstawowe jej założenia. Prezentuje wzory współczynnika Pearsona, kowariancji oraz statystyki $t$-Studenta.

\section{Metody}

W artykule użyto zróżnicowanych metod badawczych. Zaliczyć do nich można m.in: analizę opisową i porównawczą w części teoretycznej oraz analizę wskaźnikową i analizę korelacji liniowej w części empirycznej artykułu.

Materiał empiryczny stanowią raporty Ministerstwa Rolnictwa i Rozwoju Wsi (MRiRW, 2012a-2017a) oraz sprawozdania spółki Indykpol (2012-2017). Całościową analizę przeprowadzono za pomocą wskaźników handlu międzynarodowego, tj. współczynnika przewagi komparatywnej, współczynnika hipotetycznego eksportu oraz współczynnika konkurencyjności. Do ich obliczenia użyto danych MRiRW (2012a-2017a) oraz Narodowego Banku Polskiego (NBP, 2012-2016) dotyczących bilansu płatniczego.

W przeprowadzonej analizie korelacji liniowej zastosowano współczynnik korelacji Pearsona. W celu sprawdzenia istotności współczynnika, użyto testu statystyki $t$-Studenta.

Handel międzynarodowy odgrywa znaczącą rolę w kształtowaniu się całej branży drobiarskiej. W niniejszym artykule tematykę tę uzupełniono o interpretację wskaźników handlu międzynarodowego oraz analizę korelacji, co wypełnia lukę poznawczą, istniejącą w literaturze przedmiotu.

\section{Wyniki badania}

\subsection{Wskaźniki handlu międzynarodowego}

Drobiarstwo w Polsce to prężnie działająca branża, która należy do najszybciej rozwijających się działów przemysłu rolnospożywczego. W ciągu ostatnich 10 lat, udział polskich produktów drobiowych na arenie międzynarodowej gwałtownie wzrósł. Główną tego przyczyną było wstąpienie Polski do Unii Europejskiej (UE), kiedy zostały przyjęte wszystkie przepisy regulujące produkcję drobiu. Dyrektor Generalny Krajowej Rady Drobiarstwa - Izby Gospodarczej (KRD-IG, 2017), Ł. Dominiak, zaznaczył, że branża dro- 
biarska w Polsce charakteryzuje się doskonałą organizacją i przez możliwość dopasowania się do rynków eksportowych, wyprzedza trendy światowe. Branża jest $\mathrm{w}$ stanie konkurować cenowo $z$ najważniejszymi producentami unijnymi i światowymi, a drób produkowany w Polsce odznacza się wysoką jakością i bezpieczeństwem.

Dla pełnego zobrazowania sytuacji polskiej branży drobiarskiej w latach 2011-2016, zaprezentowano wskaźniki odnoszące się do konkurencyjności w handlu międzynarodowym. W celu określenia zmian w konkurencyjności eksportu, przez pryzmat wyników państw w międzynarodowym handlu, wyliczono i zinterpretowano:

- wskaźnik przewagi komparatywnej (RCA);

- wskaźnik hipotetycznego eksportu (HE);

- wskaźnik konkurencyjności (KT).

Za pomocą wskaźnika RCA możliwe jest określenie, czy dane państwo posiada przewagę komparatywną względem zagranicy $\mathrm{w}$ danej grupie produktowej (Olczyk, 2008, s. 62). Liczony jest on według wzoru (1):

$$
R C A=E X_{t}^{D} / I M_{t}^{D},
$$

gdzie:

$E X_{t}^{D}-$ eksport drobiu z Polski w okresie $t^{1}$ (w EUR);

$I M_{t}^{D}$ - import drobiu do Polski w okresie $t$ (w EUR).

O przewadze komparatywnej w literaturze jako pierwszy pisał D. Ricardo. Jeśli koszt alternatywny (niewykorzystane w pełni, dostępne zasoby) produkcji $\mathrm{w}$ przeliczeniu na inne dobra jest niższy w danym państwie, niż w innych państwach można mówić o przewadze komparatywnej (Krugman i Obstfeld, 2007 , s. 44). Gdy poziom RCA znajduje się powyżej jedności, oznacza to, że państwo ma przewagę komparatywną względem zagranicy $\mathrm{w}$ tej grupie produktowej. Poziom indeksu ujawnionej przewagi komparatywnej $\mathrm{w}$ analizowanych latach zaprezentowano $w$ tabeli 1.

$\mathrm{Na}$ podstawie poziomu indeksu RCA można uznać, że rynek drobiarski posiadał przewagę komparatywną względem zagranicy.

Okres toznacza lata 2011-2016.
W analizowanych latach, wynosił on powyżej 25. Oznacza to, że Polska wytwarza produkty po niższych kosztach, niż zagranica.

Wskaźnik HE zalicza się do dynamicznych miar kształtowania się pozycji konkurencyjnej (Lubiński i in., 1995, s. 25). Obliczany jest według wzoru (2):

$$
H E=E X_{0}^{D} \cdot r,
$$

gdzie:

$E X_{0}^{D}$ - eksport drobiu Polski w okresie bazowym $0^{2}$ (w EUR);

$r$ - współczynnik dynamiki globalnego importu Polski obliczany według wzoru (3):

$$
r=I_{t}^{G} / I_{0}^{G},
$$

gdzie:

$I M_{t}^{G}$ - import globalny Polski w okresie $t$ (w EUR);

$I M_{0}^{G}$ - import globalny Polski w okresie bazowym 0 (w EUR).

Wskaźnik HE służy przede wszystkim do porównywania wzrostu importu światowego $z$ tempem wzrostu eksportu danego państwa. Gdy poziom wskaźnika $H E$ jest mniejszy niż wolumen globalnego eksportu w analizowanym okresie, oznacza to, że dane państwo w pełni wykorzystało swój potencjał eksportowy. Taka sytuacja informuje o poprawie pozycji konkurencyjnej (Olczyk, 2008, ss. 56-57). W tabeli 1. Zaprezentowano poziom wskaźnika hipotetycznego eksportu branży drobiarskiej w odniesieniu do eksportu drobiu Polski w latach 2011-2016.

$\mathrm{Na}$ podstawie poziomu wskaźnika hipotetycznego eksportu w latach 2011-2016 dla branży drobiarskiej, można stwierdzić, że poprawa pozycji oferty eksportowej wystąpiła we wszystkich, analizowanych latach. Poziom wskaźnika hipotetycznego eksportu był niższy, niż wartość eksportu rzeczywistego w Polsce. Oznacza to, że branża drobiarska jest konkurencyjna na rynku zewnętrznym. Im większa różnica między rzeczywistym eksportem a hipotetycznym, tym branża jest bardziej konkurencyjna. Jedynie w 2011 roku pozycja konkurencyjna uległa pogorszeniu, gdyż po- 
ziom współczynnika HE był na tym samym poziomie, co wartość rzeczywistego eksportu drobiu Polski.

Konkurencyjność, w najprostszym ujęciu, jest połączona $z$ dodatnim saldem bilansu handlowego. Analiza konkurencyjności na danym rynku, z samej definicji, odnosi się do dłuższych okresów. Między początkowym i końcowym rokiem analizy musi upłynąć przynajmniej kilka lat. Szereg czasowy nie może być zbyt długi, ponieważ może to utrudnić oszacowanie zmian $\mathrm{w}$ konkurencyjności (Lubiński i in., 1995, s. 39). Konkurencyjność branży drobiarskiej w Polsce określono z wykorzystaniem wskaźnika (KT) obliczanego, według wzoru (4):

$$
K T=E X_{T}^{D} / E X_{0}^{D} \cdot r,
$$

gdzie:

$E X_{T}^{D}$ - eksport drobiu Polski w okresie $t$ (w EUR);

$E X_{0}^{D}$ - eksport drobiu Polski w okresie bazowym 0 (w EUR);

$r$ - współczynnik dynamiki globalnego importu Polski obliczany według wzoru (3).

Wskaźnik konkurencyjności, w konstrukcji, jest bardzo podobny do wskaźnika hipotetycznego eksportu. Poziom wskaźnika KT większy od jedności, oznacza poprawę pozycji konkurencyjnej danej branży. Poziom wskaźnika konkurencyjności w latach 2011-2016 zaprezentowano $\mathrm{w}$ tabeli 1 .

Uzyskany poziom wskaźnika konkurencyjności potwierdza wyniki otrzymane za pomocą wskaźnika hipotetycznego eksportu. Poziom wskaźnika KT, w analizowanym okresie, cechował się tendencją wzrostową. Oferta eksportowa polskiego drobiarstwa, w odniesieniu do importu globalnego Polski, charakteryzowała się poprawą pozycji konkurencyjnej w latach 2012-2016.

\subsection{Analiza korelacji liniowej}

Pozycja rynkowa drobiarstwa jest imponująca, jeszcze 10 lat temu Polska produkowała poniżej $1 \mathrm{mln}$ ton drobiu. Natomiast eksport wynosił około 130 tys. ton (Czekała, 2016).
W latach 2011-2016, zaobserwować można było rosnące wartości eksportu produktów drobiowych oraz zmniejszający się import. Rosnący eksport był podstawowym czynnikiem rozwoju branży drobiarskiej w Polsce w ostatniej dekadzie.

Mięso drobiowe można uznać za polską specjalność eksportową. Około 90\% żywca oraz mięsa drobiowego trafia na rynek UE. Ważną kwestią, przy tak dużych obrotach, jest dywersyfikacja rynku zbytu. Obecnie dokonuje się ona na rynkach poza unijnych takich, jak: Hongkong, Wietnam, Benin, Ghana, Zjednoczone Emiraty Arabskie, czy Egipt (MRiRW, 2016b, s. 27).

W celu porównania zależności między wybranymi wskaźnikami handlu międzynarodowego, zaprezentowano analizę korelacji liniowej przy pomocy współczynnika Pearsona. Analizie poddano cztery zmienne, tj. współczynnik przewagi komparatywnej i konkurencyjności całej branży drobiarskiej oraz przychody i eksport drobiu w Indykpol w latach 2011-2016. Dane dotyczące eksportu i przychodów Indykpol zaprezentowano w tabeli 2.

Analiza korelacji jest narzędziem matematycznym, które pozwala określić siłę oraz kierunek zależności między dwiema zmiennymi $x$ i $y$. Korelacja między zmiennymi $x$ i $y$ jest miarą siły (stopnia) liniowego związku między nimi. Możliwa jest korelacja dodatnia lub ujemna, zależna jest ona od przyjmowanych wartości przez zmienne $x$ i $y$ (Kuroś, 2005 , s. 273). Korelacja dodatnia występuje, gdy wzrostowi poziomu jednej zmiennej odpowiada wzrost średniego poziomu drugiej zmiennej. Natomiast korelacja ujemna, gdy wzrostowi poziomu jednej zmiennej odpowiada spadek średniego poziomu drugiej zmiennej. Współczynnik korelacji przyjmuje poziom z przedziału $[-1 ; 1]$. Doskonała współzależność między cechami występuje, gdy współczynnik ten przyjmuje poziom -1 lub 1 .

Siłę zależności między dwiema zmiennymi, wyrażoną za pomocą współczynnika korelacji liniowej Pearsona $\left(r_{x, y}\right)$, oblicza się zgodnie ze wzorem (5): 


$$
r_{x, y}=\operatorname{cov}(x, y) /(S(x) \cdot S(y)),
$$

gdzie:

$x$ - empiryczne wartości zmiennej niezależnej $x$;

$y$ - empiryczne wartości zmiennej zależnej $y$;

$S(x)$ - odchylenie standardowe zmiennej $x$;

$S(y)$ - odchylenie standardowe zmiennej $y$;

$\operatorname{cov}(x, y)$ - kowariancja między zmiennymi $x$ i $y$, liczona według wzoru (6):

$$
\operatorname{cov}(x, y)=\frac{1}{n} \sum_{i=1}^{n}\left(x_{i}-\bar{x}\right)\left(y_{i}-\bar{y}\right),
$$

gdzie:

$x_{i}-\bar{x}$ - różnica między wartościami zmiennej $x$ i średnią arytmetyczną;

$y_{i}-\bar{y}-$ różnica między wartościami zmiennej $y$ i średnią arytmetyczną;

$n$ - liczba obserwacji $(n=6)$.

Testowanie hipotez statystycznych, czyli współczynnika korelacji, polega na sprawdzeniu istotności parametrów. W tym celu użyto testu $t$-Studenta. Stawiane są następujące hipotezy: hipoteza zerowa: $H_{0}: r_{x, y}=0$, oznaczająca brak zależności liniowej między zmiennymi, wobec alternatywnej: $H_{1}: r_{x, y} \neq 0$. W celu przeprowadzenia oceny siły związku między tymi zmiennymi przyjęto poziom istotności $\alpha=0,05$. Wartość krytyczna statystyki $t$, odczytana przy czterech stopniach swobody i poziomie istotności 0,05 wynosi 2,776. Weryfikacja prawdziwości hipotezy $H_{0}$ ustalana jest na podstawie statystyki $t$, wyrażonej wzorem (7):

$$
t=\left(r_{(x, y)} \sqrt{n-2}\right) / \sqrt{1-r_{x, y}^{2}},
$$

gdzie:

$r_{x, y}$ - współczynnik korelacji;

$n-2$ - stopnie swobody, gdzie $n$ oznacza liczebność próby $(n=6)$.

W celu zbadania istnienia zależności między zmiennymi $x$ i $y$ w latach 2011-2016, zaprezentowano współczynniki korelacji odnoszące się do czterech zmiennych: współczynnika przewagi komparatywnej i współczynnika konkurencyjności odnoszących się do całej branży drobiarskiej (przyjęte jako zmienna $x$ ) oraz przychody ze sprzedaży i eksport Indykpol (przyjęte jako zmienna y). Poziomy współczynników korelacji liniowej Pearsona oraz wyniki testu $t$-Studenta zaprezentowano w tabeli 3. i tabeli 4.

Między współczynnikiem przewagi komparatywnej a przychodami ze sprzedaży Indykpol istnieje słaba korelacja o kierunku ujemnym $\left(r_{1}=-0,57\right)$. Wraz ze wzrostem przychodów Indykpol, następuje spadek współczynnika przewagi komparatywnej (i odwrotnie). W celu sprawdzenia przypuszczenia, wykorzystano test $t$-Studenta na istotność współczynnika korelacji liniowej. Statystyka $t_{1}$ wyniosła $-1,4$. $Z$ tablic rozkładu t-Studenta odczytano wartość krytyczna $t_{\alpha}(0,05 ; 4)=2,776$. Ponieważ $\left|t_{1}\right|<t_{\alpha}$, nie ma podstaw do odrzucenia hipotezy zerowej. Oznacza to, że parametr $r_{1}$ jest nieistotny statystycznie, czyli nie występuje zależność między współczynnikiem przewagi komparatywnej a przychodami ze sprzedaży Indykpol.

Poziom współczynnika korelacji między współczynnikiem przewagi komparatywnej a eksportem drobiu w Indykpol wyniósł $r_{2}=0,05$. Natomiast wartość statystyki $t$-Studenta $t_{2}=0,10$, która również jest niższa od wartości krytycznej $t_{\alpha}$. Oznacza to, że nie występuje zależność między współczynnikiem RCA a eksportem drobiu $\mathrm{w}$ analizowanych latach.

Poziom współczynnika przewagi komparatywnej nie był uzależniony od osiągniętych przychodów ze sprzedaży Indykpol, ani eksport nie był determinowany przez wskaźnik RCA całej branży drobiarskiej.

Współczynnik korelacji między współczynnikiem konkurencyjności a przychodami ze sprzedaży Indykpol w analizowanym okresie jest równy $r_{3}=0,99$. Wskazuje on na wysoką współzależność między zmiennymi. Może to oznaczać, że wraz ze wzrostem współczynnika konkurencyjności, występował wzrost przychodów ze sprzedaży. Na podstawie oszacowanej wartości współczynnika korelacji $z$ próby, obliczono wartość statystyki $t$, która 
wyniosła $t_{3}=17,91$. Ponieważ $\left|t_{3}\right|>t_{\alpha}, H_{0}$ odrzucono na korzyść hipotezy alternatywnej. Współczynnik konkurencyjności branży drobiarskiej ma istotny wpływ na przychody ze sprzedaży Indykpol.

Wartość współczynnika korelacji między współczynnikiem konkurencyjności a eksportem drobiu w Indykpol wynosi $r_{4}=1,00$. Wartość statystyki testowej wynosi wówczas $t_{4}=28,96$. Wartość krytyczna statystyki była mniejsza od empirycznej $\left|t_{4}\right|>t_{\alpha}$, więc hipotezę zerową o braku korelacji między współczynnikiem konkurencyjności a eksportem odrzucono.

\section{Zakończenie}

Z analizy wybranych wskaźników handlu międzynarodowego, wynika kilka pozytywnych wniosków dla branży drobiarskiej. Branża drobiarska charakteryzowała się wysoką konkurencyjnością oraz istotną przewagą komparatywną. Produkty drobiarskie, produkowane w Polsce charakteryzowały się niższym nakładem kosztów w porównaniu z zagranicą.

Przeprowadzona analiza korelacji wykazała, że nie występuję zależność między współczynnikiem przewagi komparatywnej branży drobiarskiej a przychodami i eksportem Indykpol. Oznacza to, że poziom współczynnika przewagi komparatywnej nie był $\mathrm{w}$ żadnym stopniu uzależniony od tych zmiennych. Analiza korelacji między współczynnikiem konkurencyjności a przychodami i eksportem Indykpol, wykazała istotną zależność między tymi zmiennymi. Przedstawione zmienne $\mathrm{w}$ dużym stopniu były uzależnione od siebie.

Analiza korelacji potwierdziła przypuszczenie, że między branżą drobiarską a Indy$\mathrm{kpol}$ zachodziło silne oddziaływanie. Indykpol rozwija swoją produkcję równolegle $z$ całą branżą drobiarską.

\section{Bibliografia}

Czekała, B. (2016). Polski drób jest potęga. Pobrane 15.10.2017 z https://www.topagrar.pl.

Dudkiewicz, N. (2017). Rozwój branży drobiarskiej $w$ Polsce a sytuacja finansowa Indykpol SA $w$ latach 2011-2016. Nieopublikowana praca licencjacka. Uniwersytet Mikołaja Kopernika, Toruń.

Indykpol. (2012-2017). Sprawozdanie finansowe Indykpol za lata 2012-2016. Pobrane 10.10.2017 z https://www.indykpol.pl.

KRD-IG. (2017). Pobrane 10.10.2017 z http:// www.kipdip.org.pl.

Krugman, P.R., i Obstfeld, M. (2007). Ekonomia międzynarodowa. Warszawa: PWN.

Kuroś, S. (2005). Korelacja. W: W. Bulsza (red.), Biostatystyka. Kraków: UJ.

Lubiński, M., Michalski, T., i Misala, J. (1995). Wybrane mierniki międzynarodowej pozycji konkurencyjnej gospodarki. W: M. Lubiński (red.), Międzynarodowa konkurencyjność gospodarki, pojęcie i sposób mierzenia. Warszawa: Instytut Rozwoju i Studiów Strategicznych.

MRiRW. (2012a-2017a). Handel zagraniczny towarami rolno-spożyczymi w latach 2011-2016. Pobrane 11.10.2017 z https://www.minrol.gov.pl.

MRiRW. (2016b). Program Rozwoju Gtównych Rynków Rolnych w Polsce na lata 2016-2020. Pobrane 10.10.2017 z http://www.minrol.gov.pl.

NBP. (2012-2016). Bilans ptatniczy. Pobrane 14.10.2017 z http://www.nbp.pl.

Olczyk, M. (2008). Konkurencyjność. Teoria i praktyka. Warszawa: CeDeWu.

\section{Informacje uzupełniające}

Wkład autorski: autor zaakceptował ostateczną wersję artykułu.

Źródła finansowania: artykuł został w całości sfinansowany ze środków własnych autora.

Uwagi: wyniki badania byly zaprezentowane w innej formie, tj. pracy licencjackiej Dudkiewicz (2017). 
Aneks

Tabela 1.

Eksport i import drobiu Polski (w EUR) oraz wskaźniki handlu międzynarodowego polskiej branży drobiarskiej w latach 2011-2016

\begin{tabular}{crcccc}
\hline Lata & Eksport & Import & $\begin{array}{c}\text { Wskaźnik przewagi } \\
\text { komparatywnej }\end{array}$ & $\begin{array}{c}\text { Wskaźnik } \\
\text { hipotetycznego eksportu }\end{array}$ & $\begin{array}{c}\text { Wskaźnik } \\
\text { konkurencyjności }\end{array}$ \\
\hline 2011 & 904341,00 & 35302,00 & 25,62 & 904341,00 & 1,00 \\
2012 & 1027833,00 & 40096,00 & 25,63 & 925442,75 & 1,16 \\
2013 & 1117290,00 & 44380,00 & 25,18 & 927155,21 & 1,27 \\
2014 & 1370427,00 & 54128,00 & 25,32 & 1004358,68 & 1,68 \\
2015 & 1655070,00 & 63299,00 & 26,15 & 1054224,81 & 2,13 \\
2016 & 1787540,00 & 79908,00 & 22,37 & 1084571,37 & 2,37 \\
\hline
\end{tabular}

Źródło: Opracowanie własne na podstawie MRiRW (2012a-2017a) oraz NBP (2012-2016).

Tabela 2.

Przychody ze sprzedaży oraz eksport Indykpol w latach 2011-2016 (w tys. PLN)

\begin{tabular}{rcc}
\hline Lata & Przychody ze sprzedaży & Eksport \\
\hline 2011 & 975907,00 & 155493,00 \\
2012 & 1012793,00 & 183369,00 \\
2013 & 1002187,00 & 185913,00 \\
2014 & 1150029,00 & 231636,00 \\
2015 & 1256186,00 & 288317,00 \\
2016 & 1336922,00 & 307854,00 \\
\hline
\end{tabular}

Żródło: Opracowanie własne na podstawie Indykpol (2012-2017).

Tabela 3.

Współczynnik korelacji między współczynnikiem przewagi komparatywnej branży drobiarskiej a zmiennymi opisującymi działalność Indykpol w latach 2011-2016

\begin{tabular}{lcc}
\hline \multicolumn{1}{c}{ Nazwa zmiennej } & Współczynnik przewagi komparatywnej & Statystykat \\
\hline przychody ze sprzedaży & $-0,57$ & $-1,40$ \\
eksport drobiu & 0,05 & 0,10 \\
\hline
\end{tabular}

Żródło: Obliczenia własne.

Tabela 4.

Współczynnik korelacji między współczynnikiem konkurencyjności branży drobiarskiej a zmiennymi opisującymi działalność Indykpol w latach 2011-2016

\begin{tabular}{lcc}
\hline \multicolumn{1}{c}{ Nazwa zmiennej } & Współczynnik konkurencyjności & Statystykat \\
\hline przychody ze sprzedaży & 0,99 & 17,91 \\
eksport drobiu & 1,00 & 28,96 \\
\hline
\end{tabular}

Żródło: Obliczenia własne. 
International trade indicators and selected aspects of the Indykpol SA activity in the years $2011-2016$

\section{Abstract}

Motivation: The increase in consumption of poultry meat and the greater attention of consumers about health, influenced indirectly the development of the poultry industry in Poland. The specifics of this industry and the interpretation of the changes that are taking place in it, which is lacking in the literature on the subject, were the main motivation of choosing the subject of this article.

Aim: The aim of the article is to show the relationship between the international trade indicators of the poultry industry and selected results of Indykpol's activity.

Results: Based on the analysis, it has been shown that the competitiveness indicator has a significant impact on selected variables related to Indykpol's activity. In the case of the comparative advantage indicator, there were no relationships between variables.

Keywords: poultry industry; international trade indicators; analysis of linear correlation; Indykpol JEL: CO2; F10; O10 